\title{
Endothelin and the Renal Vasculature
}

\author{
Zhengrong Guan • Edward W. Inscho \\ Department of Physiology, Georgia Health Sciences University, Augusta, Ga., USA
}

\begin{abstract}
The endothelin (ET) system comprises a family of three isopeptides (ET-1, ET-2, and ET-3) involved in diverse physiological and pathophysiological events. ET-1 is the major renal peptide that exerts its biological activity by binding to $E T_{A}$ and $E T_{B}$ receptors. Both $E T_{A}$ and $\mathrm{ET}_{\mathrm{B}}$ receptors are expressed by renal microvascular smooth muscle cells, where activation causes vasoconstriction. $\mathrm{ET}_{\mathrm{B}}$ receptors are also expressed by microvascular endothelial cells, where activation leads to vasodilator responses. ET-1 influences preglomerular and postglomerular microvascular tone and thus can significantly influence renal hemodynamics. Alteration of renal ET-1 synthesis and receptor expression has been reported in cardiovascular diseases, and could contribute to renal injury by altering renal microvascular reactivity. In this brief review, we will try to summarize what is known about ET control of renal microvascular function.

Copyright $\odot 2011$ S. Karger AG, Basel
\end{abstract}

Since endothelin (ET) was discovered in 1988 [1], three distinct ET isopeptides have been classified: ET-1, ET-2, and ET-3 [2]. Initially, ET was considered to be of endothelial origin. It is now clear that ET is synthesized and released from many vascular and nonvascular cell types, including renal epithelial cells [3-5]. ET-1 is the predominant isoform produced by the vasculature and is constitutively secreted from the endothelium, where it acts in a paracrine/autocrine manner on adjacent endothelial or vascular smooth muscle cells (VSMC). ET-1 is produced from big ET-1 catalyzed by ET-converting enzymes present in endothelial cells and is reportedly the most potent and long-lasting vasoconstrictor [1]. Approximately $80 \%$ of secreted ET-1 is released into the basolateral compartment, whereas only a limited amount of ET-1 enters the circulation [6]. Generally, plasma ET-1 concentrations range between 0.5 and 5 pм in healthy human subjects $[4,7]$. Interestingly, levels of immunoreactive ET are higher in the kidney inner medulla than any other organ or tissue [8], implying an important physiological role for ET-1 in regulating renal function. 
ET influences diverse physiological and pathophysiological mechanisms by activation of distinct $\mathrm{ET}_{\mathrm{A}}$ and $\mathrm{ET}_{\mathrm{B}}$ receptor subtypes [3-5]. In the vasculature, $\mathrm{ET}_{\mathrm{A}}$ and $\mathrm{ET}_{\mathrm{B}}$ receptors are expressed by VSMC, while endothelial cells mainly express $\mathrm{ET}_{\mathrm{B}}$ receptors. Activation of $\mathrm{ET}_{\mathrm{A}}$ and $\mathrm{ET}_{\mathrm{B}}$ receptors on VSMC increases intracellular $\mathrm{Ca}^{2+}$ concentration $\left(\left[\mathrm{Ca}^{2+}\right]_{\mathrm{i}}\right)$, leading to increased vascular tone $[4,5]$. Activation of endothelial $\mathrm{ET}_{\mathrm{B}}$ receptors stimulates release of nitric oxide $(\mathrm{NO})$ and prostacyclin leading to vasodilatation [9]. Additionally, $\mathrm{ET}_{\mathrm{B}}$ receptors also serve as 'clearance receptors' to sequester ET-1 from the plasma $[10,11]$. Accordingly, blockade or deletion of $\mathrm{ET}_{\mathrm{B}}$ receptors tends to elevate ET-1 levels. Competition-binding studies reveal that $\mathrm{ET}_{\mathrm{A}}$ and $\mathrm{ET}_{\mathrm{B}}$ receptors have different binding affinities for the three $\mathrm{ET}$ isoforms. $\mathrm{ET}_{\mathrm{A}}$ receptors have a higher affinity for ET-1 and ET-2, and a weaker affinity for ET-3. $\mathrm{ET}_{\mathrm{B}}$ receptors, on the other hand, display similar affinities for all three ET isopeptides [3]. These receptorbinding characteristics have been widely used to identify tissue distribution of receptors.

In the kidney, evidence indicates that ET-1 is produced locally and regulates renal hemodynamics by acting on preglomerular and postglomerular microvascular reactivity. ET-1 is also involved in sodium and water transport, and cell proliferation $[4,5]$. Alteration of renal ET-1 levels and receptor expression are implicated in cardiovascular disease development. This review will focus on the role of ET peptides in the renal microcirculation.

\section{Endothelin Receptor Expression in Kidney}

Early studies using receptor-binding, immunocytochemical, and pharmacological tools revealed that almost every renal vascular and tubular cell type expresses $\mathrm{ET}_{\mathrm{A}}$ and/or $\mathrm{ET}_{\mathrm{B}}$ receptors, but the expression levels vary greatly between different regions of the kidney and across species $[4,5]$. In the canine kidney, $\mathrm{ET}_{\mathrm{A}}$ and $\mathrm{ET}_{\mathrm{B}}$ receptor ratios average 22:78, 40:60, and 50:50 in cortical, medullary, and papillary membranes, respectively [12], while in rat kidneys, the regional $\mathrm{ET}_{\mathrm{A}} /$ $\mathrm{ET}_{\mathrm{B}}$ receptor ratios were 50:50, 30:70, and 90:10, respectively [13]. ET receptors are expressed in high levels in the renal medulla, particularly in the inner medulla $[14,15]$. Positron emission tomography makes it possible to quantify receptor concentration by measuring receptor-bound radioligands in vivo. This approach revealed that medullary $\mathrm{ET}_{\mathrm{B}}$ receptor expression is double that of the cortex in rabbit kidney [15]. Similarly, $\mathrm{ET}_{\mathrm{B}}$ receptor expression is nearly four times greater in the human renal medulla than in the cortex (33:9) [15], but the $\mathrm{ET}_{\mathrm{A}} / \mathrm{ET}_{\mathrm{B}}$ receptor distribution is similar between the cortex and medulla (30:70) [16].

Little is known regarding how $\mathrm{ET}_{\mathrm{A}}$ and $\mathrm{ET}_{\mathrm{B}}$ receptors differentially influence renal vascular reactivity to ET-1. Most studies have employed pharmacological tools to determine the contribution of specific ET receptors in modulating 
renal microvascular function. Several studies conducted to localize ET receptor expression in renal vessels indicate that both $\mathrm{ET}_{\mathrm{A}}$ and $\mathrm{ET}_{\mathrm{B}}$ receptors are present in preglomerular and postglomerular microvessels [17-21]. $\mathrm{ET}_{\mathrm{A}}$ receptors are present in VSMC, while $\mathrm{ET}_{\mathrm{B}}$ receptors are mainly expressed in vascular and glomerular endothelial cells and are barely detectable in VSMC [17]. Radioligand-binding studies show that the proportion of $\mathrm{ET}_{\mathrm{A}}$ and $\mathrm{ET}_{\mathrm{B}}$ receptors in membranes of preglomerular vessels is 40:60 in rabbits [18] and 50:50 in rats [19]. In human kidneys, $\mathrm{ET}_{\mathrm{A}}$ receptors are present in the vasculature throughout the cortex and medulla, with low binding densities in vasa recta and glomeruli [20]. Renal and arcuate arteries express a high density of $\mathrm{ET}_{\mathrm{A}}$ receptors at 90-95\% of total ET receptors [21]. Additionally, both $\mathrm{ET}_{\mathrm{A}}$ and $\mathrm{ET}_{\mathrm{B}}$ receptors are detected in rat vasa recta but they are located in pericytes and endothelial cells, respectively [17], implying that they might play different roles in regulating medullary perfusion.

\section{Effects of Endothelin on Renal Hemodynamics}

The renal microcirculatory system is a unique portal circulation characterized by two independently regulated resistance vessels (afferent and efferent arterioles) in series straddling the glomerular capillaries. The endothelial cells release a variety of vasodilators and vasoconstrictors in response to physical and chemical stimuli, shear stress, or stretch. These vasoactive substances modulate the glomerular microcirculation through autocrine and/or paracrine mechanisms to influence afferent and efferent arteriolar resistance and hence renal hemodynamics. Thus, the balance of vascular resistance conferred by afferent and efferent arterioles is a crucial factor in determining overall glomerular hemodynamics.

A role for ET in regulating the renal microcirculation has been substantiated by numerous in vivo and in vitro studies in different animal models. The kidney is highly sensitive to exogenous ET-1 compared to other organs [22]. Almost all in vivo studies show that infusion of exogenous ET-1 produces a marked and prolonged renal vasoconstriction marked by profound reductions in renal blood flow (RBF) and glomerular filtration rate (GFR) reflecting increased renal vascular resistance [12, 23-31]. However, the relative contribution of ET receptors to the ET-1-mediated vasoconstriction is variable among species and results are controversial. In canine kidneys, ET-1-induced reduction of RBF and GFR was abolished by $\mathrm{ET}_{\mathrm{A}}$ receptor blockade [12], implicating $\mathrm{ET}_{\mathrm{A}}$ receptors in regulating renal vascular reactivity. Furthermore, infusion of a highly selective $\mathrm{ET}_{\mathrm{B}}$ receptor agonist, sarafotoxin $6 \mathrm{c}(\mathrm{S} 6 \mathrm{c})$, markedly increased urine flow and sodium excretion, but had little effect on RBF and GFR [12], indicating that $\mathrm{ET}_{\mathrm{B}}$ receptors primarily regulate tubular transport compared to vascular function in dog kidneys. ET-1 is also a powerful vasoconstrictor in rabbit kidneys $[25,26]$. 
Interestingly, however, ET-1-mediated decreases in rabbit RBF reflect cortical vasoconstriction because medullary perfusion reportedly either increased [26] or did not change [32] during ET-1 infusion. ET-1-induced reduction of cortical perfusion was attenuated by $\mathrm{ET}_{\mathrm{A}}$ receptor blockade, but enhanced by $\mathrm{ET}_{\mathrm{B}}$ receptor blockade [26]. These studies indicate that ET-1-induced renal vasoconstriction in dogs and rabbits is primarily mediated by $\mathrm{ET}_{\mathrm{A}}$ receptors.

In contrast to dogs and rabbits, many in vivo studies in rats indicate that both $\mathrm{ET}_{\mathrm{A}}$ and $\mathrm{ET}_{\mathrm{B}}$ receptors mediate renal vasoconstriction induced by ET-1, but $\mathrm{ET}_{\mathrm{B}}$ receptors may play a more prominent role [27-31]. Intravenous infusion of ET-1 in anesthetized rats usually decreases RBF and GFR. This is accompanied by a transient reduction in blood pressure followed by a sustained pressor response. $\mathrm{ET}_{\mathrm{A}}$ receptor antagonists abrogated the pressor effects of ET-1, but had little effect on the renal hemodynamic response $[27,31]$. Others have shown that ET-1 and the $\mathrm{ET}_{\mathrm{B}}$ receptor ligand or agonist (ET-3 or $\mathrm{S} 6 \mathrm{c}$ ) elicited a similar reduction in $\operatorname{RBF}[28,30,31]$. The ET-1-induced reduction of RBF was partially blocked by $\mathrm{ET}_{\mathrm{A}}$ receptor antagonists and completely abolished by combined $\mathrm{ET}_{\mathrm{A} / \mathrm{B}}$ receptor blockade [30, 31]. Similar to observations in rabbits, ET-1-mediated reduction of RBF results from cortical vasoconstriction because medullary blood flow remained unchanged [33] or increased [34,35]. Collectively, these findings indicate that both $\mathrm{ET}_{\mathrm{A}}$ and $\mathrm{ET}_{\mathrm{B}}$ receptors are involved in the renal microvascular response to $\mathrm{ET}-1$, but $\mathrm{ET}_{\mathrm{B}}$ receptors play a predominant role in rats. Moreover, the ability of ET-1 to decrease RBF was exaggerated by selective $\mathrm{ET}_{\mathrm{B}}$ receptor blockade with BQ-788 [30], suggesting that ET-1 elicits both vasoconstrictor and vasodilator effects. The vasodilator component could reflect $\mathrm{ET}_{\mathrm{B}}$ receptordependent release of vasodilators or reduced ET-1 clearance due to $\mathrm{ET}_{\mathrm{B}}$ receptor blockade.

\section{Effects of Endothelin on Renal Microvascular Reactivity in vitro}

While the whole kidney studies provide in vivo evidence supporting ET-1 as a regulator of renal vascular reactivity, the data are often confounded by concomitant changes in mean arterial pressure and released circulating factors. Furthermore, the distribution of $\mathrm{ET}_{\mathrm{A}}$ and $\mathrm{ET}_{\mathrm{B}}$ receptors in different microvascular segments compromises interpretation of which ET receptors are responsible for ET-1's overall effect and to what degree they contribute to ET-1-induced alteration of renal hemodynamics. Accordingly, many in vitro models have been used to provide site-specific information. Studies have frequently utilized partially resected kidney models, with or without hydronephrosis, or isolated renal microvessels to directly visualize ET's effects on afferent and efferent arteriolar diameters.

The in vitro blood-perfused juxtamedullary nephron preparation is frequently used for direct assessment of renal microvascular reactivity while 


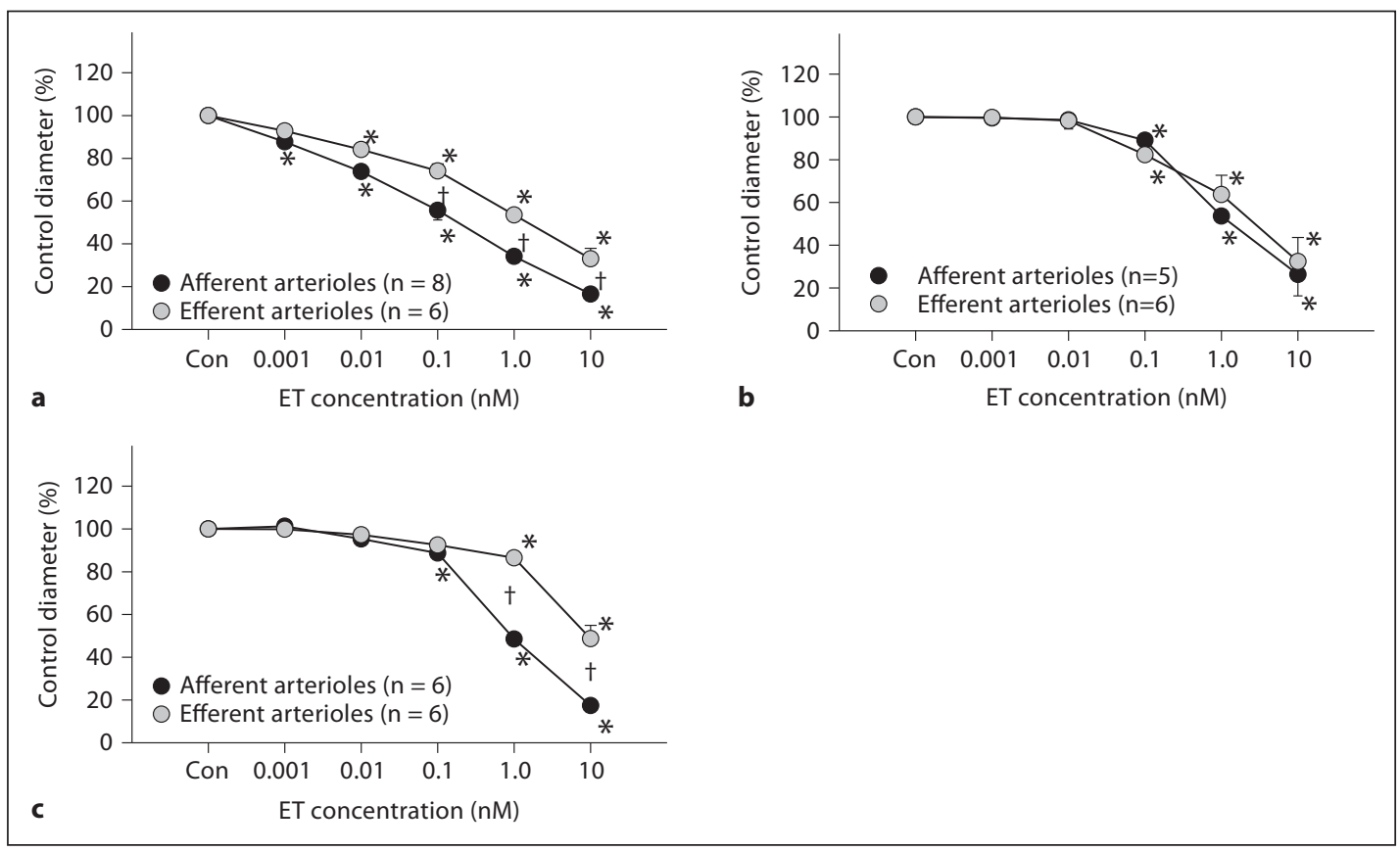

Fig. 1. Renal microvascular responses to ET peptides. Kidneys were superfused with increasing concentrations of ET-1 (a), ET-2 (b), or ET-3 (c) from $1.0 \mathrm{pm}$ to $10 \mathrm{nM}$ (5 min for each concentration), while perfusion pressure was maintained at $100 \mathrm{~mm} \mathrm{Hg}$. Afferent arteriolar diameters (black symbols) and efferent arteriolar diameters (gray symbols) were measured at 12-second intervals and calculated from the average of all measurements obtained during the final 2 min of each 5-min treatment period. Data are expressed as percent of the control diameter. Values are means $\pm S E M .{ }^{*} p<0.05$ vs. control diameter in same group; ${ }^{\dagger} p<0.05 \mathrm{vs}$. control rats at same perfusion pressure. Adapted from Inscho et al. [38].

maintaining an intact association between the vascular and tubular elements [36]. ET-1, ET-2, and ET-3 all evoke concentration-dependent vasoconstriction of afferent and efferent arterioles (fig. 1) [37-40]. ET-1 vasoconstricts afferent and efferent arterioles at concentrations of 1 and 10 pM, respectively [38]. ET-1 vasoconstricted afferent arterioles more effectively than efferent arterioles such that the afferent diameter declined by $83 \%$ of the control compared to $67 \%$ for efferent arterioles at a concentration of $10 \mathrm{nM}$. Similar to ET-1, ET-3 also yielded a greater vasoconstrictor response in afferent than efferent arterioles. ET-2, however, elicited similar degrees of vasoconstriction for afferent and efferent arterioles. The ET-1 concentration curve in afferent arterioles was significantly shifted to the right by pretreatment with $\mathrm{ET}_{\mathrm{A}}$ or $\mathrm{ET}_{\mathrm{B}}$ receptor blockers and was completely abolished by combined $\mathrm{ET}_{\mathrm{A} / \mathrm{B}}$ blockers, indicating the vasoconstrictor property of both ET receptors at preglomerular microvessels. In 
contrast, $\mathrm{ET}_{\mathrm{A}}$ receptor blockade in efferent arterioles converted ET-1-induced vasoconstriction to vasodilation at low concentrations $(0.01-0.1 \mathrm{~nm})$ while vasoconstriction was retained at higher concentrations (1-10 nM), suggesting that $\mathrm{ET}_{\mathrm{B}}$ receptors can elicit vasodilation and vasoconstriction of efferent arterioles. The dual effect of $\mathrm{ET}_{\mathrm{B}}$ receptors in efferent arterioles was confirmed using S6c, which yielded efferent arteriolar vasodilation under control conditions but vasoconstriction during $\mathrm{ET}_{\mathrm{B}}$ receptor blockade with A-192621 [38]. These observations suggest that during $\mathrm{ET}_{\mathrm{A}}$ receptor blockade, low ET-1 concentrations mainly stimulate endothelial $\mathrm{ET}_{\mathrm{B}}$ receptors, probably by releasing $\mathrm{NO}$ or prostacyclin, while higher concentrations of ET-1 shift to activating $\mathrm{ET}_{\mathrm{B}}$ receptors on VSMC in efferent arterioles.

Preferential ET-1-mediated vasoconstriction of rat afferent arterioles has been demonstrated using different experimental approaches [24, 31, 41-43]. For example, micropuncture studies in Munich-Wistar rats showed that ET-1 reduced single nephron GFR with significant increases in afferent and efferent arteriolar resistance, but particularly in afferent arterioles [41]. This is consistent with studies in hydronephrotic rat kidneys showing that ET-1 caused substantial afferent arteriolar vasoconstriction but only modest efferent arteriolar vasoconstriction $[24,42]$. Alternatively, other studies have indicated that efferent arterioles are more sensitive to ET-1 than afferent arterioles [23, 44]. Glomerular capillary pressure, as assessed by measuring stop-flow pressure, was significantly increased in response to ET, which was associated with a greater increase in efferent arteriolar resistance than in afferent arteriolar resistance [23]. Studies in isolated-perfused microvessels showed that the $\mathrm{EC}_{50}$ of ET-1 was lower in efferent arterioles (5.7 pM) compared to afferent arterioles (52 pM) [44], suggesting that ET-1 is a more potent vasoconstrictor of efferent arterioles. The explanation for the discrepancies among these studies is unclear, but may reflect differences between experimental conditions.

The aforementioned studies of ET-1 on renal microvascular reactivity mostly employed pharmacological tools to establish the contribution of ET receptors. Genetic approaches provide useful strategies to determine specific gene or protein functions. Although several ET-1 or $\mathrm{ET}_{\mathrm{B}}$ receptor knockout mouse models have been developed, only one study has been conducted to assess the distribution of ET receptors in ET-1-induced renal microvascular responsiveness in vascular $\mathrm{ET}_{\mathrm{B}}$ receptor-deficient mice and wild-type control mice [45]. The results obtained from isolated-perfused renal microvessels indicate that ET-1 more potently vasoconstricts afferent arterioles compared to efferent arterioles. Furthermore, ET-1-induced vasoconstriction involves activation of $\mathrm{ET}_{\mathrm{A}}$ receptors in afferent arterioles, but involves both $\mathrm{ET}_{\mathrm{A}}$ and $\mathrm{ET}_{\mathrm{B}}$ receptors in efferent arterioles [45]. The relative contribution of ET receptors in ET-1-induced responses in mouse renal microvessels is different from rats. Interestingly, endothelium-specific ET-1 knockout mice exhibit 10- to 12-mm Hg lower mean arterial pressure [46], suggesting a pivotal role of endogenous endothelium- 
derived ET receptor system in control of blood pressure and maintenance of vascular tone under physiological conditions. How these changes affect renal hemodynamics remains to be determined.

\section{Endothelin in Medullary Microcirculation}

Medullary perfusion is supplied by descending vasa recta (DVR) arising from juxtamedullary efferent arterioles [47]. Given the potent vasoconstrictor effect of ET-1 in juxtamedullary nephron microvasculature and expression of $\mathrm{ET}_{\mathrm{A}}$ and $\mathrm{ET}_{\mathrm{B}}$ receptors in vasa recta [17], it is not surprising that ET is also involved in regulating medullary microcirculation. Elegant studies using isolated-perfused DVR establish ET as a potent vasoconstrictor of DVR [47]. ET-1, ET-2, and ET-3 elicit potent vasoconstriction with a rank order of potency of ET-1>ET$2>$ ET-3. DVR diameter started to decrease with 0.01 pM ET-1 and almost completely collapsed at 100 pM. ET-1-induced vasoconstriction was attenuated by an $\mathrm{ET}_{\mathrm{A}}$ antagonist or a mixed $\mathrm{ET}_{\mathrm{A} / \mathrm{B}}$ receptor antagonist, whereas ET-3-induced vasoconstriction was only blocked by an $\mathrm{ET}_{\mathrm{B}}$ receptor antagonist, suggesting the dual involvement of $\mathrm{ET}_{\mathrm{A}}$ and $\mathrm{ET}_{\mathrm{B}}$ receptors. These observations, however, seem to contradict rabbit studies where infusion of ET-1 increases medullary blood flow with concurrent reduction in total RBF and cortical blood flow [26]. Conflicting outcomes probably reflect species variation (rats vs. rabbits) and different experimental conditions (in vitro vs. in vivo). The intense vasoconstriction of DVR by ET-1 suggests a potentially important role of ET-1 for the development of renal injury in cases where the renal ET system is upregulated [47].

\section{Endogenous Endothelin-1 in Regulating Renal Microvascular Tone}

While both in vivo and in vitro studies provide compelling evidence that ET-1 regulates renal hemodynamics by influencing preglomerular and postglomerular microvascular tone, there is conflicting evidence establishing that ET-1 regulates renal vascular tone under basal conditions. Infusion of $\mathrm{ET}_{\mathrm{A}}$ receptor

antagonists did not change RBF or GFR in conscious rats $[9,27,48]$, implying that $\mathrm{ET}_{\mathrm{A}}$ receptors may not regulate renal hemodynamics under basal conditions. In contrast, combined $\mathrm{ET}_{\mathrm{A} / \mathrm{B}}$ receptor blockade with bosentan markedly reduced glomerular capillary pressure with a significant increase in preglomerular resistance while postglomerular resistance remained unchanged [48]. ET $_{B}$ receptor blockade with RES-701-1 or BQ-788 significantly decreased RBF without affecting arterial blood pressure $[9,29]$. Reduction of RBF was prevented by pretreatment with L-NAME (NO synthase inhibitor) and ibuprofen (cyclooxygenase inhibitor). These findings suggest that endogenous ET-1 contributes to 
basal renal vascular resistance by $\mathrm{ET}_{\mathrm{B}}$ receptor-dependent release of $\mathrm{NO}$ and/or prostacyclin. Overall, these studies imply that $\mathrm{ET}_{\mathrm{B}}$ receptor-mediated vasodilation may influence renal microcirculatory function under physiological conditions. For example, exogenous ET-1 or S6c normally vasoconstricts normal rat afferent arterioles [38]; however, when rats are fed a high-salt diet, ET-1 and S6c-mediated vasoconstriction is attenuated and even converted to vasodilation at low ET-1 concentrations. ET $_{\mathrm{B}}$ receptor expression in preglomerular microvessels is increased during salt loading [40]. Accordingly, salt-induced upregulation of $\mathrm{ET}_{\mathrm{B}}$ receptor expression may counteract $\mathrm{ET}_{\mathrm{A}}$ and $\mathrm{ET}_{\mathrm{B}}$ receptor activation in VSMC and facilitate sodium excretion by increasing RBF. The physiological mechanisms behind salt-induced increases in $\mathrm{ET}_{\mathrm{B}}$ receptor expression need further investigation.

\section{Endothelin in Renal Autoregulation}

Autoregulation is an important mechanism protecting selected organs against injury from variations in arterial pressure. This protective mechanism is accomplished in the kidney by precise pressure-mediated adjustments of preglomerular resistance via myogenic and tubuloglomerular feedback responses [49]. Although earlier studies indicated that ET-1 was not involved in renal autoregulation $[50,51]$, recent studies suggest that ET-1 might interact with NO in modulating or resetting renal autoregulation [52, 53]. L-NAME augmentation of autoregulation was eliminated by the nonselective $\mathrm{ET}_{\mathrm{A} / \mathrm{B}}$ receptor antagonist bosentan or the $\mathrm{ET}_{\mathrm{B}}$ receptor blocker BQ-788 [52]. A subsequent study by Shi et al. [53] showed that myogenic reactivity was significantly impaired by pretreatment with BQ-788, suggesting that ET-1 may be involved in resetting renal autoregulation by release of $\mathrm{NO}$ via $\mathrm{ET}_{\mathrm{B}}$ receptor stimulation. Interestingly, exposure of macula densa cells to ET-1 caused a rapid increase of signal-nephron GFR, a measure of tubuloglomerular feedback responsiveness, without changes in systemic and renal hemodynamics [54]. This study suggests that ET-1 may influence tubuloglomerular feedback responses, but the mechanism(s) underlying this is (are) unclear.

\section{Endothelin-Induced Intracellular Signaling in Renal Microvessels}

Both $\mathrm{ET}_{\mathrm{A}}$ and $\mathrm{ET}_{\mathrm{B}}$ receptors belong to the $\mathrm{G}$ protein-coupled receptor family. ET receptor activation is coupled to many second messenger pathways including phospholipase $\mathrm{C}$, phospholipase $\mathrm{D}$, protein kinase $\mathrm{C}$, mitogen-activated protein kinases, cytosolic $\mathrm{Ca}^{2+}$, and tyrosine kinase $[4,5]$. Application of ET-1 to VSMC increases $\left[\mathrm{Ca}^{2+}\right]_{\mathrm{i}}$ via influx of extracellular $\mathrm{Ca}^{2+}$ and mobilization of $\mathrm{Ca}^{2+}$ from intracellular stores [55]. $\mathrm{ET}_{\mathrm{A}}$ receptors are coupled with activation of 


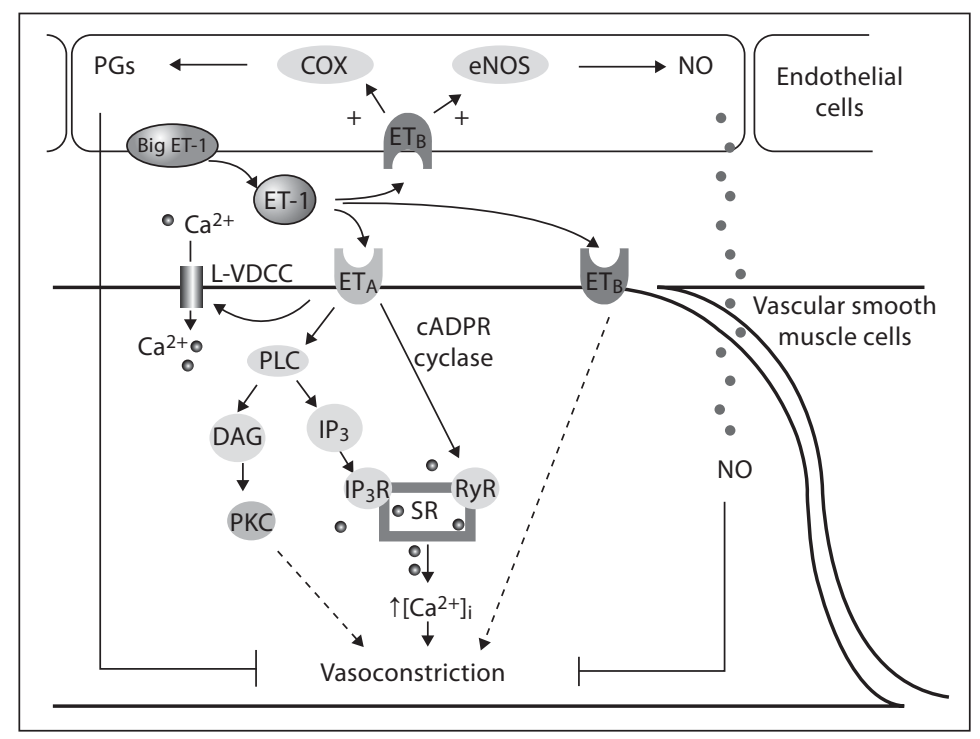

Fig. 2. Intracellular ET pathway in renal preglomerular microvessels. ET-1 is produced from big ET-1 catalyzed by the ET-converting enzyme from endothelial cells. Activation of $\mathrm{ET}_{\mathrm{A}}$ receptors in VSMC increases intracellular calcium concentration $\left(\left[\mathrm{Ca}^{2+}\right]_{i}\right)$ via influx of extracellular $\mathrm{Ca}^{2+}$ through activating L-type voltage-dependent $\mathrm{Ca}^{2+}$ channels (L-VDCC) and mobilization of $\mathrm{Ca}^{2+}$ from sarcoplasmic reticulum (SR) through activating inositol triphosphate $\left(\mathrm{IP}_{3}\right)$ pathway and cyclic adenine diphosphate ribose (CADPR) cyclase/ryanodine receptor (RyR) pathways. Activation of endothelial $\mathrm{ET}_{\mathrm{B}}$ receptors releases $\mathrm{NO}$ and prostaglandins ( $\mathrm{PGs}$ ), causing vasodilation. Activation of $\mathrm{ET}_{\mathrm{B}}$ receptors in vascular smooth muscle cells mediates vasoconstriction via as yet undefined intracellular mechanisms (dashed line).

phospholipase $\mathrm{C}$ to generate diacylglycerol and inositol triphosphate, which in turn stimulates $\mathrm{Ca}^{2+}$ release from intracellular stores, ultimately causing vasoconstriction (fig. 2). In contrast, activation of $\mathrm{ET}_{\mathrm{B}}$ receptors in endothelial cells stimulates release of $\mathrm{NO}$ and/or prostacyclin, which increase cGMP and cAMP formation, leading to vasodilation. Downstream signaling of $\mathrm{ET}_{\mathrm{B}}$ receptor activation in VSMC still remains uncertain.

In the kidney, L-type voltage-dependent $\mathrm{Ca}^{2+}$ channels (L-VDCC) are important for regulating basal vascular tone and preglomerular microvascular responses to many vasoconstrictors [49]. However, there are conflicting results whether ET-1-induced vasoconstriction involves L-VDCC signaling. Several in vivo and in vitro studies indicate that L-VDCC blockade has little effect on ET-1 or $\mathrm{ET}_{\mathrm{B}}$ receptor-mediated renal vasoconstriction $[39,55,56]$, while others found that ET-1-induced renal vasoconstriction is via L-VDCC-dependent influx of extracellular $\mathrm{Ca}^{2+}$ [57-59], specifically in afferent arterioles but not in efferent arterioles $[24,60]$. Studies in freshly isolated preglomerular microvascular 
VSMC found that ET-1 evoked a biphasic increase in $\left[\mathrm{Ca}^{2+}\right]_{\mathrm{i}}$, with a rapid initial increase followed by a sustained plateau [55]. The sustained plateau was eliminated by superfusion with $\mathrm{Ca}^{2+}$-free medium while the initial peak was unaltered, indicating that ET-1 increases $\left[\mathrm{Ca}^{2+}\right]_{\mathrm{i}}$ in preglomerular microvascular VSMC by stimulating $\mathrm{Ca}^{2+}$ release from intracellular stores and $\mathrm{Ca}^{2+}$ influx from extracellular fluid. In contrast, ET-3 or S6c only evoked small and monophasic increases in $\left[\mathrm{Ca}^{2+}\right]_{\mathrm{i}}[39,55]$. Subsequent studies revealed that ET-1-induced increases in $\left[\mathrm{Ca}^{2+}\right]_{\mathrm{i}}$ were unchanged by blockade of L-VDCC with diltilazem or $\mathrm{Ni}^{2+}$. This was confirmed with both in vivo and in vitro studies. Nifedipine only slightly attenuated the reduction of RBF when ET-1 or S6c were applied at very high doses, while ET-1-induced juxtamedullary afferent arteriolar vasoconstriction was slightly inhibited by diltilazem only at very low ET-1 concentrations (1 and $10 \mathrm{pm}$ ) [39]. Although L-VDCC inhibition led to slightly different observations in these two experimental settings, the results suggest that L-VDCC do not play a critical role in ET-1 and $\mathrm{ET}_{\mathrm{B}}$ receptor-mediated afferent arteriolar vasoconstriction in rats. Alternatively, studies in hydronephrotic rat kidney showed that nifedipine completely eliminated ET-1-induced afferent arteriolar vasoconstriction, indicating a prominent role for L-VDCC in ET-1-mediated afferent arteriolar responses [24].

Recent studies indicate that cyclic adenine diphosphate ribose (cADPR) cyclase/ryanodine receptor-mediated $\mathrm{Ca}^{2+}$ signaling pathways contribute to ET1 -mediated vasoconstriction in afferent arterioles [61, 62]. Blockade of ribosyl cyclase with nicotinamide reduced ET-1-mediated $\left[\mathrm{Ca}^{2+}\right]_{\mathrm{i}}$ signaling by $60 \%$ in rat preglomerular microvascular VSMC. This effect is largely due to stimulation of NADPH oxidase by ET-1 via $\mathrm{ET}_{\mathrm{A}}$ receptor activation because application of tempol, apocynin, or a specific cADPR cyclase inhibitor attenuated $\left[\mathrm{Ca}^{2+}\right]$ i signaling induced by ET-1 but not by S6c [61]. The finding of cADPR and RyR signaling in ET-1-induced renal microvasoconstriction was further demonstrated in vivo as well as in the mice lacking the major mammalian ADPR cyclase (CD38-/-) [62]. These studies suggest that the superoxide-NADPH oxidase pathway contributes to the preglomerular microvascular response to ET-1 through cADPR.

Additionally, other studies suggest that activation of $\mathrm{ET}_{\mathrm{A}}$ and $\mathrm{ET}_{\mathrm{B}}$ receptors in the renal microvasculature are also coupled with a variety of second messenger pathways such as cytochrome $P-450$ metabolites [37], RhoA/Rho-kinase pathway [63], reactive oxygen species [64], and NO [65]. The role of prostacyclin in ET-1 responses is controversial. Some have reported that ET receptor activation is coupled to prostacyclin $[66,67]$, whereas others found that ET-1-mediated vasoconstriction was unaffected by COX inhibition $[65,68,69]$ or that ET-1 stimulated a vasoconstrictor cyclooxygenase metabolite [70]. Interested readers are referred to some recent excellent reviews which provide more comprehensive discussions of the ET-1-mediated intracellular pathways in renal and nonrenal vascular beds $[4,5,71,72]$. 


\section{Impact of Endothelin-1 on Endothelial Function in Hypertension}

Since discovery of this powerful vasoconstrictor released from the endothelium, activation of the ET system has been reported in a number of models of endothelial dysfunction, including hypertension [5]. Impaired renal vasodilation has been suggested as one of the mechanisms initiating salt-sensitive hypertension [73]. Studies in Dahl salt-sensitive hypertensive rats showed increased vascular and renal ET-1 protein content and impaired endothelium-dependent renal vasodilation. Treatment with an $\mathrm{ET}_{\mathrm{A}}$ receptor antagonist not only prevented activation of tissue ET-1, but also prevented renal artery injury and endothelial dysfunction, suggesting that $\mathrm{ET}_{\mathrm{A}}$ receptor-dependent increases in renal ET-1 level contributes to renal vascular injury in Dahl salt-sensitive hypertensive rats [74]. Together, these studies indicate an important role of ET-1 in mediating endothelial injury and development of hypertensive renal injury. The precise roles of ET-1 in hypertension, however, are still under investigation.

\section{Conclusion}

Collectively, ET-1-mediated vasoconstriction of afferent arterioles is coupled with activation of $\mathrm{ET}_{\mathrm{A}}$ and $\mathrm{ET}_{\mathrm{B}}$ receptors with a predominant role of $\mathrm{ET}_{\mathrm{A}}$ receptors in dogs, rabbits, and mice, and a predominant role of $\mathrm{ET}_{\mathrm{B}}$ receptors in rats. ET-1-mediated vasoresponsiveness in efferent arterioles seems to be exclusively coupled to $\mathrm{ET}_{\mathrm{B}}$ receptors, except in mice. Low ET-1 concentrations activate endothelial $\mathrm{ET}_{\mathrm{B}}$ receptors leading to vasodilation, while high ET-1 concentrations activate $\mathrm{ET}_{\mathrm{B}}$ receptors expressed in VSMC evoking vasoconstriction. Additionally, endogenous ET-1 may contribute to control of basal renal vascular resistance via vasodilator influence of $\mathrm{ET}_{\mathrm{B}}$ receptors in rats. The magnitude of ET-1-mediated vasoresponsiveness depends upon the segmental distribution of ET receptor expression as well as species variation. Different responses of afferent and efferent arterioles to ET-1 may certainly have a distinct impact on glomerular capillary pressure and hence alter glomerular hemodynamics. Any changes in ET receptor expression or renal ET-1 levels may play a crucial role in renal injury under pathological conditions by impairing renal hemodynamics.

\section{Acknowledgements}

The authors would like to acknowledge grant support from National Institutes of Health (PO1 HL095499) for E.W. Inscho and the American Heart Association (10SDG3770010) for Z. Guan. 


\section{References}

-1 Yanagisawa M, Kurihara H, Kimura S, Tomobe Y, Kobayashi M, Mitsui Y, Yazaki Y, Goto K, Masaki T: A novel potent vasoconstrictor peptide produced by vascular endothelial cells. Nature 1988;332:411-415.

2 Inoue A, Yanagisawa M, Kimura S, Kasuya Y, Miyauchi T, Goto K, Masaki T: The human endothelin family: three structurally and pharmacologically distinct isopeptides predicted by three separate genes. Proc Natl Acad Sci USA 1989;86:2863-2867.

3 Sakurai T, Yanagisawa M, Takuwa Y, Miyazaki H, Kimura S, Goto K, Masaki T: Cloning of a cDNA encoding a nonisopeptide-selective subtype of the endothelin receptor. Nature 1990;348:732-735.

-4 Simonson MS: Endothelins: multifunctional renal peptides. Physiol Rev 1993;73:375-411.

5 Kohan DE, Rossi NF, Inscho EW, Pollock DM: Regulation of blood pressure and salt homeostasis by endothelin. Physiol Rev 2011;91:1-77.

6 Wagner OF, Christ G, Wojta J, Vierhapper H, Parzer S, Nowotny PJ, Schneider B, Waldhausl W, Binder BR: Polar secretion of endothelin-1 by cultured endothelial cells. J Biol Chem 1992;267:16066-16068.

7 Treiber FA, Jackson RW, Davis H, Pollock JS, Kapuku G, Mensah GA, Pollock DM: Racial differences in endothelin-1 at rest and in response to acute stress in adolescent males. Hypertension 2000;35:722-725.

8 Kitamura K, Tanaka T, Kato J, Ogawa T, Eto $\mathrm{T}$, Tanaka K: Immunoreactive endothelin in rat kidney inner medulla: marked decrease in spontaneously hypertensive rats. Biochem Biophys Res Commun 1989;162:38-44.

9 Matsuura T, Miura K, Ebara T, Yukimura T, Yamanaka S, Kim S, Iwao H: Renal vascular effects of the selective endothelin receptor antagonists in anaesthetized rats. Br J Pharmacol 1997;122:81-86.

10 Fukuroda T, Fujikawa T, Ozaki S, Ishikawa K, Yano M, Nishikibe M: Clearance of circulating endothelin-1 by $\mathrm{ET}_{\mathrm{B}}$ receptors in rats. Biochem Biophys Res Commun 1994;199:1461-1465.
11 Bagnall AJ, Kelland NF, Gulliver-Sloan F, Davenport AP, Gray GA, Yanagisawa M, Webb DJ, Kotelevtsev YV: Deletion of endothelial cell endothelin B receptors does not affect blood pressure or sensitivity to salt. Hypertension 2006;48:286-293.

12 Brooks DP, DePalma PD, Pullen M, Nambi $\mathrm{P}$ : Characterization of canine renal endothelin receptor subtypes and their function. J Pharmacol Exp Ther 1994;268:1091-1097.

13 Gellai M, DeWolf R, Pullen M, Nambi P: Distribution and functional role of renal ET receptor subtypes in normotensive and hypertensive rats. Kidney Int 1994;46:12871294.

14 Waeber C, Hoyer D, Palacios JM: Similar distribution of [125I] sarafotoxin- $6 \mathrm{~b}$ and [125I] endothelin-1, -2, -3 binding sites in the human kidney. Eur J Pharmacol 1990;176:233-236.

- 15 Johnstrom P, Rudd JH, Richards HK, Fryer TD, Clark JC, Weissberg PL, Pickard JD, Davenport AP: Imaging endothelin $\mathrm{ET}_{\mathrm{B}}$ receptors using [18F]-BQ3020:in vitro characterization and positron emission tomography (microPET). Exp Biol Med 2006;231:736-740.

16 Nambi P, Pullen M, Wu HL, Aiyar N, Ohlstein EH, Edwards RM: Identification of endothelin receptor subtypes in human renal cortex and medulla using subtype-selective ligands. Endocrinology 1992;131:1081-1086.

17 Wendel M, Knels L, Kummer W, Koch T: Distribution of endothelin receptor subtypes $\mathrm{ET}_{\mathrm{A}}$ and $\mathrm{ET}_{\mathrm{B}}$ in the rat kidney. J Histochem Cytochem 2006;54:1193-1203.

18 Edwards RM, Trizna W: Characterization of 125I-endothelin-1 binding to rat and rabbit renal microvasculature. J Pharmacol Exp Ther 1995;274:1084-1089.

19 De Leon H, Garcia R: Characterization of endothelin receptor subtypes in isolated rat renal preglomerular microvessels. Regul Pept 1995;60:1-8.

20 Kuc R, Davenport AP: Comparison of endothelin-A and endothelin-B receptor distribution visualized by radioligand binding versus immunocytochemical localization using subtype selective antisera. J Cardiovasc Pharmacol 2004;44(Suppl 1):S224-S226. 
21 Davenport AP, Kuc RE, Maguire JJ, Harland SP: $\mathrm{ET}_{\mathrm{A}}$ receptors predominate in the human vasculature and mediate constriction. J Cardiovasc Pharmacol 1995;26(Suppl 3):S265-S267.

-22 Clozel M, Clozel JP: Effects of endothelin on regional blood flows in squirrel monkeys. J Pharmacol Exp Ther 1989;250:1125-1131.

23 King AJ, Brenner BM, Anderson S: Endothelin: a potent renal and systemic vasoconstrictor peptide. Am J Physiol Renal Physiol 1989;256:F1051-1058.

-24 Loutzenhiser R, Epstein M, Hayashi K, Horton C: Direct visualization of effects of endothelin on the renal microvasculature. Am J Physiol Renal Physiol 1990;258:F61-F68.

25 Evans RG, Bergstrom G, Cotterill E, Anderson WP: Renal haemodynamic effects of endothelin- 1 and the $\mathrm{ET}_{\mathrm{A}} / \mathrm{ET}_{\mathrm{B}}$ antagonist TAK-044 in anaesthetized rabbits. J Hypertens 1998;16:1897-1905.

26 Evans RG, Madden AC, Oliver JJ, Lewis TV: Effects of $\mathrm{ET}_{\mathrm{A}^{-}}$and $\mathrm{ET}_{\mathrm{B}}$-receptor antagonists on regional kidney blood flow, and responses to intravenous endothelin-1, in anaesthetized rabbits. J Hypertens 2001;19:1789-1799.

-27 Pollock DM, Opgenorth TJ: Evidence for endothelin-induced renal vasoconstriction independent of $\mathrm{ET}_{\mathrm{A}}$ receptor activation. Am J Physiol Regul Integr Comp Physiol 1993;264:R222-R226.

28 Cristol JP, Warner TD, Thiemermann C, Vane JR: Mediation via different receptors of the vasoconstrictor effects of endothelins and sarafotoxins in the systemic circulation and renal vasculature of the anaesthetized rat. $\mathrm{Br}$ J Pharmacol 1993;108:776-779.

29 Gellai M, Fletcher T, Pullen M, Nambi P: Evidence for the existence of endothelin-B receptor subtypes and their physiological roles in the rat. Am J Physiol Regul Integr Comp Physiol 1996;271, R254-R261.

-30 Just A, Olson AJ, Arendshorst WJ: Dual constrictor and dilator actions of $\mathrm{ET}_{\mathrm{B}}$ receptors in the rat renal microcirculation: interactions with $\mathrm{ET}_{\mathrm{A}}$ receptors. Am J Physiol Renal Physiol 2004;286, F660-F668.

-31 Wellings RP, Corder R, Warner TD, Cristol JP, Thiemermann C, Vane JR: Evidence from receptor antagonists of an important role for $\mathrm{ET}_{\mathrm{B}}$ receptor-mediated vasoconstrictor effects of endothelin-1 in the rat kidney. $\mathrm{Br}$ Pharmacol 1994;111:515-520.
32 Denton KM, Shweta A, Finkelstein L, Flower RL, Evans RG: Effect of endothelin-1 on regional kidney blood flow and renal arteriole calibre in rabbits. Clin Exp Pharmacol Physiol 2004;31:494-501.

33 Vassileva I, Mountain C, Pollock DM: Functional role of $\mathrm{ET}_{\mathrm{B}}$ receptors in the renal medulla. Hypertension 2003;41:1359-1363.

34 Brodsky S, Abassi Z, Wessale J, Ramadan R, Winaver J, Hoffman A: Effects of A-192621.1, a specific endothelin-B antagonist, on intrarenal hemodynamic responses to endothelin-1. J Cardiovasc Pharmacol 2000;36:S311-S313.

35 Hercule HC, Oyekan AO: Role of NO and cytochrome P-450-derived eicosanoids in ET-1-induced changes in intrarenal hemodynamics in rats. Am J Physiol Regul Integr Comp Physiol 2000;279:R2132-R2141.

36 Casellas D, Navar LG: In vitro perfusion of juxtamedullary nephrons in rats. Am J Physiol Renal Physiol 1984;246:F349-F358.

37 Imig JD, Pham BT, LeBlanc EA, Reddy KM, Falck JR, Inscho EW: Cytochrome P450 and cyclooxygenase metabolites contribute to the endothelin-1 afferent arteriolar vasoconstrictor and calcium responses. Hypertension 2000;35:307-312.

38 Inscho EW, Imig JD, Cook AK, Pollock DM: $\mathrm{ET}_{\mathrm{A}}$ and $\mathrm{ET}_{\mathrm{B}}$ receptors differentially modulate afferent and efferent arteriolar responses to endothelin. Br J Pharmacol 2005;146:1019-1026.

39 Pollock DM, Jenkins JM, Cook AK, Imig JD, Inscho EW: L-type calcium channels in the renal microcirculatory response to endothelin. Am J Physiol Renal Physiol 2005;288:F771-F777.

40 Schneider MP, Inscho EW, Pollock DM: Attenuated vasoconstrictor responses to endothelin in afferent arterioles during a high-salt diet. Am J Physiol Renal Physiol 2007;292:F1208-F1214.

41 Kon V, Yoshioka T, Fogo A, Ichikawa I: Glomerular actions of endothelin in vivo. J Clin Invest 1989;83:1762-1767.

42 Takenaka T, Forster H, Epstein M: Protein kinase $\mathrm{C}$ and calcium channel activation as determinants of renal vasoconstriction by angiotensin II and endothelin. Circ Res 1993;73:743-750. 
43 Saito M, Homma S, Yamatsu I, Sato M, Ohshima N: Visualization of renal microcirculation in isolated Munich-Wistar rat kidneys: effects of endothelin-1 on renal hemodynamic activity. Jpn J Pharmacol 1994;66:221-229.

44 Lanese DM, Yuan BH, McMurtry IF, Conger JD: Comparative sensitivities of isolated rat renal arterioles to endothelin. Am J Physiol Renal Physiol 1992;263:F894-F899.

45 Schildroth J, Rettig-Zimmermann J, Kalk P, Steege A, Fahling M, Sendeski M, Paliege A, Lai EY, Bachmann S, Persson PB, Hocher B, Patzak A: Endothelin type A and B receptors in the control of afferent and efferent arterioles in mice. Nephrol Dial Transplant 2011;26:779-789.

46 Kisanuki YY, Emoto N, Ohuchi T, Widyantoro B, Yagi K, Nakayama K, Kedzierski RM, Hammer RE, Yanagisawa H, Williams SC, Richardson JA, Suzuki $\mathrm{T}$, Yanagisawa M: Low blood pressure in endothelial cell-specific endothelin 1 knockout mice. Hypertension 2010;56:121-128.

47 Pallone TL, Zhang Z, Rhinehart K: Physiology of the renal medullary microcirculation. Am J Physiol Renal Physiol 2003;284:F253-F266.

48 Qiu C, Samsell L, Baylis C: Actions of endogenous endothelin on glomerular hemodynamics in the rat. Am J Physiol Regul Integr Comp Physiol 1995;269:R469-R473.

49 Navar LG, Arendshorst WJ, Pallone TL, Inscho EW, Imig JD, Bell PD: Microcirculation; in Tuma RFD, Wa LK (eds): Handbook of Physiology 2008. San Diego, Elsevier, p.550-683.

50 Takabatake T, Ise T, Ohta K, Kobayashi K: Effects of endothelin on renal hemodynamics and tubuloglomerular feedback. Am J Physiol Renal Physiol 1992;263:F103-F108.

-51 Berthold H, Munter K, Just A, Kirchheim HR, Ehmke H: Contribution of endothelin to renal vascular tone and autoregulation in the conscious dog. Am J Physiol Renal Physiol 1999;276:F417-F424.

52 Kramp R, Fourmanoir P, Caron N: Endothelin resets renal blood flow autoregulatory efficiency during acute blockade of NO in the rat. Am J Physiol Renal Physiol 2001;281:F1132-F1140.
53 Shi Y, Lau C, Cupples WA: Interactive modulation of renal myogenic autoregulation by nitric oxide and endothelin acting through $\mathrm{ET}_{\mathrm{B}}$ receptors. Am J Physiol Regul Integr Comp Physiol 2007;292:R354-R361.

54 Romano G, Giagu P, Favret G, Bartoli E: Effect of endothelin 1 on proximal reabsorption and tubuloglomerular feedback. Kidney Blood Press Res 2000;23:360-365.

55 Schroeder AC, Imig JD, LeBlanc EA, Pham BT, Pollock DM, Inscho EW: Endothelinmediated calcium signaling in preglomerular smooth muscle cells. Hypertension 2000;35:280-286.

56 Fretschner M, Endlich K, Gulbins E, Lang RE, Schlottmann K, Steinhausen M: Effects of endothelin on the renal microcirculation of the split hydronephrotic rat kidney. Ren Physiol Biochem 1991;14:112-127.

57 Madeddu P, Yang XP, Anania V, et al: Efficacy of nifedipine to prevent systemic and renal vasoconstrictor effects of endothelin. Am J Physiol 1990;259:F304-F311.

58 Yukimura T, Miura K, Yamashita Y, Shimmen T, Okumura M, Yamanaka S, Saito M, Yamamoto K: Effects of the calcium channel antagonist nicardipine on renal action of endothelin in dogs. Contrib Nephrol 1991;90:105-110.

59 Takahashi K, Katoh T, Fukunaga M, Badr KF: Studies on the glomerular microcirculatory actions of manidipine and its modulation of the systemic and renal effects of endothelin. Am Heart J 1993;125:609-619.

60 Edwards RM, Trizna W, Ohlstein EH: Renal microvascular effects of endothelin. Am J Physiol Renal Physiol 1990;259:F217-F221.

61 Fellner SK, Arendshorst W: Endothelin-A and $-\mathrm{B}$ receptors, superoxide, and $\mathrm{Ca}^{2+}$ signaling in afferent arterioles. Am J Physiol Renal Physiol 2007;292:F175-F184.

62 Thai TL, Churchill GC, Arendshorst WJ: NAADP receptors mediate calcium signaling stimulated by endothelin-1 and norepinephrine in renal afferent arterioles. Am J Physiol Renal Physiol 2009;297:F510-F516.

63 Cavarape A, Endlich N, Assaloni R, Bartoli E, Steinhausen M, Parekh N, Endlich K: Rhokinase inhibition blunts renal vasoconstriction induced by distinct signaling pathways in vivo. J Am Soc Nephrol 2003;14:37-45. 
64 Just A, Whitten CL, Arendshorst WJ: Reactive oxygen species participate in acute renal vasoconstrictor responses induced by $\mathrm{ET}_{\mathrm{A}}$ and $\mathrm{ET}_{\mathrm{B}}$ receptors. Am J Physiol Renal Physiol 2008;294:F719-F728.

65 Just A, Olson AJ, Falck JR, Arendshorst WJ: $\mathrm{NO}$ and NO-independent mechanisms mediate $\mathrm{ET}_{\mathrm{B}}$ receptor buffering of ET-1induced renal vasoconstriction in the rat. Am J Physiol Regul Integr Comp Physiol 2005;288:R1168-R1177.

-66 Hirata Y, Matsuoka H, Kimura K, Sugimoto T, Hayakawa H, Suzuki E, Sugimoto T: Role of endothelium-derived relaxing factor in endothelin-induced renal vasoconstriction. J Cardiovasc Pharmacol 1991;17(Suppl 7): S169-S171.

67 Chou SY, Porush JG: Renal actions of endothelin-1 and endothelin-3: interactions with the prostaglandin system and nitric oxide. Am J Kidney Dis 1995;26:116-123.

68 Cao LQ, Banks RO: Cardiorenal actions of endothelin, part II: effects of cyclooxygenase inhibitors. Life Sci 1990;46:585-590.

69 Duval M, D’Orleans-Juste P: Endothelin-1 induces an endothelin-A-receptor-dependent and L-NAME-sensitive vasoconstriction in the isolated perfused guinea-pig kidney. J Cardiovasc Pharmacol 2000;36:S241-S243.
70 Munger KA, Takahashi K, Awazu M, Frazer M, Falk SA, Conger JD, Badr KF: Maintenance of endothelin-induced renal arteriolar constriction in rats is cyclooxygenase dependent. Am J Physiol 1993;264:F637-F644.

71 Bouallegue A, Daou GB, Srivastava AK: Endothelin-1-induced signaling pathways in vascular smooth muscle cells. Curr Vasc Pharmacol 2007;5:45-52.

72 Kedzierski RM, Yanagisawa M: Endothelin system: the double-edged sword in health and disease. Annu Rev Pharmacol Toxicol 2001;41:851-876.

73 Simchon S, Manger WM, Carlin RD, Peeters LL, Rodriguez J, Batista D, Brown T, Merchant NB, Jan KM, Chien S: Saltinduced hypertension in Dahl salt-sensitive rats. Hemodynamics and renal responses. Hypertension 1989;13:612-621.

74 Barton M, Vos I, Shaw S, Boer P, D’Uscio LV, Grone HJ, Rabelink TJ, Lattmann T, Moreau P, Luscher TF: Dysfunctional renal nitric oxide synthase as a determinant of salt-sensitive hypertension: mechanisms of renal artery endothelial dysfunction and role of endothelin for vascular hypertrophy and Glomerulosclerosis. J Am Soc Nephrol 2000;11:835-845.

Prof. Edward W. Inscho

Department of Physiology, Georgia Health Sciences University

CA Building, CA31371120, 15th Street

Augusta, GA 30912 (USA)

Tel. +1 706721 5615, E-Mail einscho@georgiahealth.edu 